\title{
The Use of Telenursing through The Nursing Care
}

\author{
Maria Franciska Vianney Boro ${ }^{1 *}$, Rr. Tutik Sri Hariyati² \\ ${ }^{I}$ Magister Kepemimpinan dan Manajemen Keperawatan, Fakultas Ilmu Keperawatan, Universitas \\ Indonesia, Depok, Jawa Barat \\ ${ }^{2}$ Afiliasi Departemen DKKD Fakultas Ilmu Keperawatan, Universitas Indonesia, Depok, Jawa \\ Barat \\ Coresponding Person: vianyboro@gmail.com
}

\begin{abstract}
Background: Information technology that is increasingly developing, especially in the world of health today, makes people more sensitive to the professionalism of nursing care. But in Indonesia itself, against the background of the archipelago, the achievement of professional nursing care still seems to be an obstacle. This condition also resulted in the weak quality of health received, especially for regions that have not been exposed to technological developments. Telenursing is present as an answer to address the health problems of the nursing world as one of the nurses' efforts to help achieve equitable community welfare. Telenursing itself is one of the telecommunications technologies used to provide nursing care using information and data obtained remotely.

Purpose: To illustrate the implementation of the use of telenursing through the provision of nursing care by professional nurses that is systematically integrated and focuses on the effectiveness of the results of the applicative telenursing itself.

Methods: Literature review is to use PRISMA by examining several online databases that are adapted to the application of telenursing in nursing practice.

Results: this shows that the presence of telenursing can help improve more comprehensive access and improve the quality of health services to achieve community welfare.

Conclusion: Telenursing must be utilized appropriately and integrated so that the main objective of fulfilling public health, especially for those who are far from health services can be achieved.
\end{abstract}

Keywords:

Telenursing; Telehealth; Nursing Practice

\section{LATAR BELAKANG}

Telenursing merupakan bagian dari Telehealth yang diterapkan pada keperawatan. Yang telah berjalan sejauh ini yaitu dengan menggunakan telepon, tetapi dalam 20 tahun terakhir atau lebih, aktivitasnya telah sangat meningkat. Penekanan keperawatan di negara maju dan berkembang berbeda, sehingga penekanan telenursing juga bervariasi di antara mereka, seperti yang diuraikan di bawah ini. Berbagai layanan dan teknologi yang dicakup oleh telenursing termasuk konsultasi jarak jauh; pengawasan perawatan diri oleh pasien di tempat tinggal mereka; transfer data yang relevan, seperti untuk 
konsultasi dan penelitian pasien, statistik, atau tujuan lain; dan penyediaan perpustakaan dan basis data elektronik. Ini sangat penting di negara-negara berkembang, melalui fasilitasi pembelajaran jarak jauh (Eren \& Webster, 2017).

Kesehatan adalah keadaan sehat baik secara fisik, mental spiritual maupun sosial yang memungkinkan setiap orang untuk hidup produktif secara sosial dan ekonomi. Sedangkan upaya kesehatan adalah setiap kegiatan untuk memelihara dan meningkatkan kesehatan yang dilakukan oleh pemerintah dan atau masyarakat (UU No. 36 Tahun 2006). Salah satu tujuan pembangunan kesehatan di Indonesia adalah pemerataan pelayanan kesehatan ke seluruh daerah di Indonesia (KEMENKES, 2015).

Seiring berkembangnya zaman, terkhusus di era 4.0 ini, beriringan dengan semakin mudahnya akses terkait teknologi informasi, dimanfaatkan dalam lingkup kesehatan untuk membantu menjawab segala permasalahan kesehatan yang ada. Hal tersebut juga dipandang sebagai suatu peluang untuk meningkatkan kualitas asuhan keperawatan dan meningkatkan jangkauan pelayanan keperawatan khususnya bagi masyarakat diseluruh Indonesia, termaksud masyarakat di daerah terpencil dan jauh (rural area) (Scotia, 2014).

Dalam Rencana Strategis (Renstra) Kementerian Kesehatan tahun 2015-2019, „meningkatnya sistem informasi kesehatan terintegrasie menjadi salah satu dari 12 sasaran strategis Kementerian Kesehatan (KEMENKES, 2015).

Salah satu teknologi keperawatan yang terus berkembang adalah telehealth nursing atau telenursing. Diketahui bahwa telenursing saat ini sedang tumbuh, mengingat kehadirannya di berbagai negara, dengan bukti kuat dan manfaat penggunaannya. Ini terbukti menjadi alat yang efisien untuk membantu negara mengatasi hambatan geografis dan memberikan informasi perawatan kesehatan kepada penduduk (SouzaJunior, Mendes, Mazzo, \& Godoy, 2016).

Pertumbuhan telenursing saat ini dikategorikan sangat cepat di banyak negara karena adanya beberapa faktor yang mempengaruhi yaitu diantaranya tercapainya biaya perawatan kesehatan yang lebih murah, peningkatan jumlah populasi lansia dan penyakit kronis, dan peningkatan cakupan perawatan kesehatan untuk jarak jauh seperti di pedesaan, wilayah kecil, atau berpenduduk jarang. Cakupan telenursing dalam perawatan melalui penggunaan telepon untuk layanan kesehatan dan orientasi. Negara dengan jumlah publikasi penelitian terbesar adalah Amerika Serikat dengan 14 (37,8\%), diikuti oleh Kanada dan Inggris (Souza et al., 2019).

WHO mengamati bahwa tanggung jawab perawat meningkat secara baik dalam beberapa dekade terakhir, karena jangkauan kegiatannya yang meluas, ini dicontohkan oleh konsep praktisi perawat. Mereka dideskripsikan oleh International Council Nursisng (ICN) sebagai "perawat terdaftar yang telah memperoleh basis pengetahuan, keterampilan membuat keputusan dan kompetensi klinis untuk praktik yang diperluas selain dari seorang perawat terdaftar (Eren \& Webster, 2017). 
Di antara banyak manfaatnya, telenursing dapat membantu mengatasi kekurangan tenaga perawat, mengurangi jarak dan menghemat waktu perjalanan, dan menjaga pasien setelah keluar dari rumah sakit (Kumar \& Snooks, 2013). Telenursing juga dapat memberikan peluang untuk pendidikan pasien, teleconsultations keperawatan, pemeriksaan hasil tes medis, dan bantuan kepada dokter dalam pelaksanaan protokol perawatan medis.

Telenursing dapat mengurangi hari rawat di RS sehingga berdampak pada berkurangnya biaya perawatan (efektif dan efisiensi dari sisi biaya kesehatan), mengurangi jumlah kunjungan ke pelayanan kesehatan, peningkatan jumlah cakupan pelayanan keperawatan dalam jumlah yang lebih luas dan merata, dapat dimanfaatkan dalam bidang pendidikan keperawatan (model distance learning) dan perkembangan riset keperawatan berbasis informatika kesehatan dan meningkatkan kepuasan perawat dan pasien terhadap pelayanan keperawatan yang diberikan serta meningkatkan mutu pelayanan perawatan di rumah (home care). Selain itu telenursing juga meningkatkan rasa aman (safety) perawat dan klien (Kumar \& Snooks, 2013).

Dari pemaparan diatas menunjukan bahwa pentingnya penerapan telenursing di layanan keperawatan, sangat membantu pemenuhan kesejahteraan masyarakat terkhusus di daerah tertinggal atau perbatasan.

Telenursing diharapkan mampu menjadi jawaban dari permasalahan pemberian asuhan keperarawatan yang belum merata di Indonesia, dan menjadi pembaharu di era perkembangan teknologi saat ini. Diharapkan bahwa pasien, atau masyarakat yang masih minim informasi kesehatan atau belum tersentuh oleh pelayanan kesehatan dapat terbantu dengan adanya telenursing.

\section{TUJUAN}

Literature review ini bertujuan untuk menggambarkan implementasi dari penggunaan Sistem Informasi Kesehatan (SIK) berbasis telenursing melalui pemberian asuhan keperawatan oleh perawat profesional yang terintegrasi secara sistematis dan berfokus pada efektivitas hasil dari aplikatif telenursing itu sendiri.

\section{METODE}

Literature review ini menggunakan PRISMA untuk menggambarkan implementasi penggunaan telenursing terhadap pemberian asuhan keperawatan dan kepuasan pasien. Penulis menggunakan berbagai jenis metode penelitian termasuk metode kuantitatif dan kualitatif untuk menggambarkan implementasi penggunaan telenursing terhadap hasil asuhan keperawatan dan kepuasan pasien dalam pelaksanaan di lapangan, dilihat dari kualitas perawat dalam pemberian asuhan hingga kemandirian pasien dalam menjawab masalah kesehatannya.

Penulis melakukan beberapa proses pencarian jurnal yang relevan dengan implementasi telenursing terhadap asuhan keperawatan dan kepuasan pasien, dengan menelusuri beberapa database online seperti diantaranya Science Direct, PROQUEST, Scopus, Ebsco, dan Google Scholar, setelah melalui tahap pemilahan yang sesuai dengan pembahasan terkait. 
Hasil dari literature review ini menggambarkan dan menjelaskan implementasi telenursing dalam praktik asuhan keperawatan

\section{HASIL}

World Health Oraganization (WHO) mendefinisikan telehealth sebagai "pemberian layanan perawatan kesehatan, di mana pasien dan penyedia layanan dipisahkan oleh jarak. Telehealth menggunakan TIK (teknologi informasi dan komunikasi) untuk pertukaran informasi untuk diagnosis dan perawatan penyakit dan cedera, penelitian dan evaluasi, dan untuk pendidikan berkelanjutan para profesional kesehatan. "Istilah telehealth umumnya digunakan bersama dengan" atau secara sinonim dengan telenursing, telemedicine, teleconsultation, telehomecare, e-health dan informatika. "Meskipun telehealth dimulai dengan telepon, ia sekarang menggabungkan beragam teknologi yang terus berkembang, termasuk konferensi video, pemantauan jarak jauh, pendidikan telehealth, perangkat digital dan bentuk lain dari komunikasi berbasis internet (Rawat, 2018).

Istilah seperti telehealth atau telemedicine, digunakan secara bergantian untuk merujuk pada pelayanan menggunakan tehnologi elektronik pada pasien dalam keterbatasan jarak. Pada aplikasinya, penggunaan telehealth sangat membantu terkait pemenuhan kesejahteraan kesehatan untuk pasien dan keluarga. Dalam lingkup asuhan keperawatan itu sendiri, ada telenursing yang hadir untuk memecahkan masalah kesehatan bersamasama dengan sejawat atau pelaku dan profesi kesehatan lainnya.

Telenursing didefenisikan sebagai perpaduan layanan telekomunikasi dan keperawatan setiap kali ada jarak fisik yang substansial antara perawat atau antara pasien dan perawat (Amudha, Nalini, Alamelu, Badrinath, \& Sharma, 2017). American Nurses Association (2001) mendefinisikan telenursing sebagai subjek telehealth di mana fokusnya adalah pada praktik profesi tertentu (yaitu keperawatan). Meskipun penggunaan teknologi mengubah media penyampaian asuhan keperawatan dan mungkin memerlukan kompetensi terkait dengan penggunaannya untuk memberikan asuhan keperawatan, proses keperawatan dan ruang lingkup praktik tidak berbeda dengan telenursing. Perawat yang terlibat dalam praktik telenursing terus menilai, merencanakan, mengintervensi, dan mengevaluasi hasil asuhan keperawatan, tetapi mereka melakukannya dengan menggunakan teknologi seperti Internet, komputer, telepon, alat penilaian digital, dan peralatan telemonitoring. Mengingat bahwa layanan kesehatan yang sekarang disediakan melalui teleteknologi telah berkembang, istilah telehealth digunakan untuk menangkap luasnya layanan (Schlachta-Fairchild L, 2008)

Bentuk-bentuk telenursing dapat berupa triage telenursing, call-center services, konsultasi melalui secure email messaging system, konseling melalui hotline service, audio atau videoconferencing antara pasien dengan petugas kesehatan atau dengan sesama petugas kesehatan, discharge planning telenursing, home-visit telenursing dan pengembangan websites sebagai pusat informasi dan real-time counseling pada pasien (COACH, 2015) 
Padila at all (2018) dalam penelitiannya mengungkapkan bahwa dengan adanya perangkat telenursing maka, masalah- masalah terkait penyediaan SDM perawat yang kurang memadai dibeberapa RS dapat teratasi, termaksud didalamanya jika terjadi halhal yang tidak dingginginkan seperti terjadinya kejadian luar biasa (KLB), yang tidak bisa meninggalkan ruangan karena pasien membludak, tetap bisa terkoordinir dengan baik dengan adanya sistem telenursing ini sebagai saran komunikasi dan monitoring tindakan keperawatan. Dengan digunakan SIM telenursing ini di RS, tidak menutup kemungkinan income RS meningkat tajam, lalu akan menambah peningkatan gaji perawat dan tim medis lainnya sehingga akan meningkat pula produktivitas dalam bekerja.

Selain itu telenursing juga membantu pasien dan keluarga untuk ikut berpartisipasi aktif dalam perawatan terutama self-management untuk penyakit kronis dan mengurangi lama perawatan (Length of Stay). Sistem ini memfasilitasi perawat memberikan informasi dan dukungan yang akurat secara online.

Telenursing dapat meningkatkatkan keinginan diri dan meningkatkan kesadaran pasien dalam kepatuhan terhadap diet, aktivitas fisik, dan perilaku sehat terkait dengan penyakit. American Nursing Association telah mempertimbangkan telenursing sebagai bagian dari telemedicine yang berfokus pada penyediaan layanan keperawatan khusus (Schlachta-Fairchild L, 2008)

Telenursing meningkatkan akses pasien ke perawatan yang berpengaruh dan efektif. Telepon, sebagai sarana komunikasi yang tersedia, semakin banyak digunakan dalam telenursing. Metode pemberian perawatan ini tidak hanya mengurangi biaya dan memfasilitasi akses ke layanan perawatan, tetapi juga meningkatkan hubungan antara pasien dan perawat (Javanmardifard, Ghodsbin, Kaviani, \& Jahanbin, 2017).

Dalam hasil penelitian Yang, Jiang, \& Li tahun 2019 mengenai 'Peran Telenursing Dalam Manajemen Pasien Dengan Diabetes' dihasilkan bahwa telenursing, sebagai alat yang berguna untuk pendidikan pasien dan intervensi perilaku, dapat membantu pasien diabetes untuk meningkatkan kontrol glikemik mereka.

Amudha at all (2017) dalam hasil penelitiannya mengungkapkan bahwa praktik Telehealth di India berlangsung lebih dari satu dekade dengan bantuan komunikasi satelit. Empat ratus node telemedicine didirikan di India oleh Indian Space Research Organisation (ISRO).

Teleconsultation, tele-education dan observasi penyakit adalah area utama yang dicakup oleh ISRO. Kemajuan teknologi informasi perawatan kesehatan membantu mengatasi kekurangan dalam infrastruktur kesehatan dan kekurangan tenaga profesional medis.

Namun pada penggunaanya, aplikasi telenursing di lapangan juga mengalami beberapa hambatan atau kekurangan yaitu tidak dapat melihat pasien, dilema etis, kesulitan teknologi, kurang kontak dengan pasien secara langsung, privasi, keamanan dan kerahasiaan, perlu bantuan teknis, biaya peralatan tinggi, kurang pengetahuan dan pendidikan yang tepat dalam menangani komputer dan internet, mengacaukan 
pembicaraan, Masalah keselamatan pasien, informasi yang tertunda atau hilang, saran yang disalahpahami.

Untuk perawat, segmen tele-keperawatan baru dan kinerjanya membutuhkan pelatihan dalam sumber daya teknologi dan dalam proses kerja baru. Untuk ini, pelatihan ini harus dimulai pada tingkat sarjana untuk mengikuti era teknologi saat ini (Souza et al., 2019).

Melalui penelitian terkait perspektif pemberi kerja dan karyawan dalam lingkup pemberian asuhan keperawatan berbasis telenursing, peneliti memberikan pandangan luas tentang keterampilan dan kompetensi yang dibutuhkan. Diketahui bahwa hasil penelitian menunjukkan bahwa pada aplikatif telenursing di lapangan membutuhkan beragam kompetensi yang dapat disusun menjadi empat kategori: kompetensi profesional, metodologis, personal, dan sosial (Christine, Bettina, Carsten, Martin, \& Thomas, 2016).

\section{PEMBAHASAN}

Sektor perawatan kesehatan harus memanfaatkan teknologi informasi untuk meningkatkan kualitas hidup, meminimalkan human-eror, mengurangi biaya, meningkatkan waktu respons dan untuk mencapai sistem perawatan kesehatan yang berpusat pada pasien. Pemerintah India juga harus berkonsentrasi dalam mendirikan perguruan tinggi medis, lembaga pelatihan untuk menawarkan dokter yang dibutuhkan, perawat dan profesional paramedis lainnya (Amudha, Nalini, Alamelu, Badrinath, \& Sharma, 2017).

Bahwasannya penerapan sistem informasi kesehatan berbasis telenursing home visite sangat di butuhkan terkhusus didaerah rawan bencana seperti Bengkulu, penyediaan fasilitas dan software aplikasi terkait telenursing home care sendiri juga sudah tersedia, namun tetap perlu beberapa penyempurnaan dan dukungan dari pemerintah setempat (Padila, Lina, Febriawati, Agustina, \& Yanuarti, 2018)

Menurut hasil penelitian dari (Rawat, 2018) manfaat dari pengunaan telenursing dibagi menjadi 2 lingkup yaitu untuk perawat dan pasien. Untuk Perawat manfaat yang diperoleh antara lain jam kerja fleksibel, gaji meningkat, perjalanan kurang, efektivitas biaya, kepuasan kerja, peluang untuk pengembangan keterampilan, waktu respon cepat, berbagi data, dan untuk pasien antara lain mendapat kemudahan dalam mengakses informasi, ekonomis, perawatan berkualitas tinggi, kepuasan pasien, layanan jarak jauh, perjalanan lebih sedikit, tidak ada antrian tunggu, nyaman, sederhana.

Telehealth menjadi solusi dalam meningkatkan kesenjangan pelayanan kesehatan yang disebabkan karena akses. Masih banyaknya daerah tertinggal dan perbatasan menjadi tantangan pemerintah dalam pengembangan telehealth. Jika pembangunan infrastruktur telehealth merata hingga Sabang sampai Merauke, maka Nawacita Presiden tercapai dalam peningkatan kualitas hidup. Perawat memiliki peran dalam upaya peningkatan layanan kesehatan di Indonesia. Intervensi secara holistik menjadi konsep perawat dalam pemberian asuhan. Perawat dapat memanfaatkan perkembangan teknologi dalam layanan telehealth. Penerapan layanan ini dilakukan dengan memberikan asuhan keperawatan berupa tindakan preventif dan rehabilitatif. Penggunaan telehealth ini 
sangat efektif dalam layanan homecare. Hal ini akan mencapai kesehatan yang mandiri, efektif, dan efisien seiring perkembangan teknologi dan informasi (Istifada, Sukihananto, \& Laagu, 2018)

\section{SIMPULAN}

Salah satu tujuan telehealth atau home visit telenursing adalah untuk meningkatkan akses yang lebih komprehensif dan meningkatkan kualitas layanan kesehatan. Dimana pasien dengan mudah memberikan kabar tentang kondisi kesehatannya setelah proses pemulihan ataupun saat mula terkena sakitnya kepada perawat, yang telah dipercaya dalam memberikan pelayanan kepada pasiennya.

Selain itu telenursing juga membantu pasien dan keluarga untuk ikut berpartisipasi aktif dalam perawatan terutama self-management untuk penyakit kronis dan mengurangi lama perawatan (Length of Stay). Sistem ini memfasilitasi perawat memberikan informasi dan dukungan yang akurat secara online.

Dengan adanya telenursing sebagai pembaharu di bidang teknologi informasi, komunikasi, memudahkan pemantauan yang memungkinkan penyedia layanan kesehatan untuk mengevaluasi status kesehatan secara jauh, memberikan intervensi pendidikan, atau memberikan perawatan kesehatan dan sosial kepada pasien di rumah mereka sudah seyogyanya diberlakukan dimasyarakat terutama rumah sakit yang menjadi rujukan sehingga menurunkan angka kesakitan dan meningkatnya derajat kesehatan dimasyarakat sehingga semakin bertambahnya angka harapan hidup di indonesia pada umumnya.

Di dalam penerapan telenursing, keterampilan interpersonal sangat penting untuk mengamati dan mengidentifikasi kondisi fisik dan mental pasien secara lebih jauh dan memiliki kemampuan untuk memenuhi kebutuhan mereka sehingga pihak RS harus selalu memberikan pelatihan secara berkala bagi tenaga medis yang terlibat. Layanan telenursing yang sukses memerlukan stabilitas teknis dan operasional harus memenuhi kebutuhan pasien. Tingkat kepercayaan yang diberikan terhadap telenursing oleh anggota keluarga yang menggunakan layanan telenursing menjadi faktor yang sangat penting.

\section{REFERENSI}

American Nurses, A. (2001). Developing telehealth protocols : a blueprint for success. Washington, DC: American Nurses Association.

Christine, C., Bettina, Z.-S., Carsten, S., Martin, S., \& Thomas, M. H. (2016). Developing a Holistic Competence Model for Telenursing Practice: Perspectives from Telenurses and Managers of Telemedical Service Centres. Journal of the International Society for Telemedicine and eHealth, 4, e22 (21-17).

COACH. (2015). 2015 CANADIAN TELEHEALTH REPORT. In. Canada: Canada's Health Informatics Association.

Eren, H., \& Webster, J. G. (2017). Telehealth and mobile health. New York: CRC Press. 
Istifada, R., Sukihananto, S., \& Laagu, M. A. (2018). PEMANFAATAN TEKNOLOGI TELEHEALTH PADA PERAWAT DI LAYANAN HOMECARE (THE UTILIZATION OF TELEHEALTH TECHNOLOGY BY NURSES AT HOMECARE SETTING). NC Nursing Current Jurnal Keperawatan, 5(1), 51.

Javanmardifard, S., Ghodsbin, F., Kaviani, M. J., \& Jahanbin, I. (2017). The effect of telenursing on self-efficacy in patients with non-alcoholic fatty liver disease: a randomized controlled clinical trial. Gastroenterology \& Hepatology from Bed to Bench, 10(4), 263-271.

KEMENKES. (2015). PERATURAN MENTERI KESEHATAN REPUBLIK INDONESIA

$\begin{array}{llll}\text { NOMOR } & 97 & \text { TAHUN } & 2015 .\end{array}$

http://www.pusdatin.kemkes.go.id/resources/download/pusdatin/lain-lain/PMK-

No-97-Th-2015-ttg-Peta-Jalan-Sistem-Informasi-Kesehatan-Tahun-20152019.pdf

Kumar, S., \& Snooks, H. (2013). Telenursing. London: Springer.

Padila, P., Lina, L. F., Febriawati, H., Agustina, B., \& Yanuarti, R. (2018). Home Visit Berbasis Sistem Informasi Manajemen Telenursing. JKS Jurnal Keperawatan Silampari, 2(1), 217-235.

Schlachta-Fairchild L, E. V., Deickman A. (2008). Patient Safety, Telenursing, and Telehealth. . USA: Hughes RG.

Scotia, T. n. J. o. T. a. T.-D. m. w. e. c. t. O. (2014). Telehealth nursing. Journal of Telemedicine and Telecare;10:239-244, 10:239-244.

Souza-Junior, V. D., Mendes, I. A. C., Mazzo, A., \& Godoy, S. (2016). Application of telenursing in nursing practice: an integrative literature review. Applied Nursing Research, 29, 254-260. doi:10.1016/j.apnr.2015.05.005

Souza, C. F. Q. d., Oliveira, D. G. d., Santana, A. D. d. S., Mulatinho, L. M., Cardoso, M. D., Pereira, E. B. F. e., \& Aquino, J. M. d. (2019). Evaluation of nurses performance in telemedicine. Rev. Bras. Enferm. Revista Brasileira de Enfermagem, 72(4), 933-939. 